\title{
Analysis of Students' Sport Attitude Levels in Vocational School of Health Care Services
}

\author{
Erdal Bal ${ }^{1} \&$ Nedim Malkoç ${ }^{1}$ \\ ${ }^{1}$ University of Healt Sciences, Department of Exercise and Sport Sciences, Istanbul, Turkey \\ Correspondence: Erdal Bal, University of Healt Sciences, Department of Exercise and Sport Sciences, Istanbul, \\ Turkey. E-mail: balerdalbilim@gmail.com
}

Received: June 23, 2020

doi:10.5539/ies.v13n9p114
Accepted: July 25, $2020 \quad$ Online Published: August 28, 2020

URL: https://doi.org/10.5539/ies.v13n9p114

\begin{abstract}
This study uses method to determine the levels of sport attitude of vocational school of health students in various health departments. It is important to determine the sports attitude level of university students. Socio-demographic information form of students consisting of 8 items was created to examine the attitude of students studying in the field of exercise, sports and health, which are among the main factors of health. In the second part of the questionnaire, "Sport-Oriented Attitude Scale" was used which is composed of 28 items and 3 sub-dimensions and validity and reliability study of the scale was performed by Şentürk (2015). A total of 382 people, $25.9 \%$ male and $74.1 \%$ female participated. Results revealed that sport attitude scores of males are higher than females', and a statistically significant difference was found $(p<0.5)$. Participants who were 28 years old and above had higher scores than others in terms of being interested in sport $(p<0.006)$, giving importance to sport $(p<0.027)$ and doing sport actively $(\mathrm{p}<0.017)$ and there was a statistically significant difference between them. However, a statistically significant difference was observed between the individuals' sport status, their income level, place of residence, age and gender.
\end{abstract}

Keywords: attitude, college, sport, students, university

\section{Introduction}

Sport is seen in the modern world as a field that increases in value day by day. Besides the economic returns from sport, it is a fact that people need it for a quality and healthy life. Compared with the past, sports fields are now located in every region of the cities. Correspondingly, the sports industry has contributed to the economy and created new work areas (Yaşar, 2020). In addition, employment has increased, the denominators in the sport have increased and improvements have been achieved in many areas like scientific studies in sports field. In parallel with these, there is a significant increase in the number of people in the sport field. Besides being able to exist in a healthy and effective body, sport is seen as a major economic area (Yetim, 2000). Over time, sport has preserved its existence with the innovations that people bring into it as they keep carrying on the process (Filiz, 2002).

Sport which takes place in an educational activity develops the feeling and ability of appreciation and meeting in common grounds and ensures its emergence (Illhan, 2008). Sport is a concept that exists in every period of people's life. It covers a process starting from infancy and continuing in adulthood. Games played as a child existed on a different side of the sport. In this way, it is an argument used in education and health with various games and movements for the development of children (Aydoğan et al., 2015). Sport has universal characteristics, regardless of any distinction that unites all classes. It also contains many cultural elements and especially includes various social structures (Yıldırım et al., 2006; Kat, 2009). People who are involved in sports activities in a regular program contribute to their physiological, physical, psychological and social development (Strong et al., 2005; Güllü \& Çiftçi, 2016; Turğut \& Yaşar, 2019). Sports activities also keep individuals away from bad habits and behavioral disorders. It is an important factor in preventing many chronic diseases. At the same time, it provides convenience and rapid improvements in the treatment of diseases (Erkan, 1992). The image created by sports on people has become a symbol of health. Then, sports in popular culture is seen as a time remaining from health, entertainment, duties and responsibilities (Solmaz \& Aydın, 2012).

When the concept of sport is analyzed from the literature, it would be observed that it has definitions that are different but with the same meaning, and its integrity would be established. According to these definitions; Sport is all of the exercise and movement trainings that promote the development of heart and breathing and it is the 
realization of energy expenditure in the movements of individuals with muscles and joints within sports activities (Şentürk, 2012). According to another definition, even though sport contains many factors, it is also a phenomenon that regulates personal and social relations. The basis of sport is human. At the present time sport is regarded as a valuable structure in terms of providing business efficiency in plans for the future, developing creative thinking and social unification (Yetim, 2011).

People react to the situations they face. This reaction is the type of behavior that the person creates within himself. Attitudes constitute the person's behavior. Concepts such as environment, social position, status, time and family have an important effect on this behavior that occurs in the person (Hünük, 2006). Demirhan and Altay (2001) explains attitude as the manner that people take against certain people, objects and developing events in their lives. Doydu et al. (2013) see attitudes as affective factors that shape the behavior of individuals. It also affects the size and degree of the person's behavior. To Şişko and Demirhan (2002); attitude is a tendency that evaluates the individual's objects in a psychological mindset and concludes their behaviors regularly (Kağıtçıbaş1, 1999). Çelik and Pulur (2011) argue that besides all these views, attitude has a feature to be measured. Behaviors can be measured using interview or grading scales.

More accurate measurement takes place when the person is observed and inferred. There are many variables during the formation of attitudes. The main ones are gender, sports history, skill level, peers, interest in sports, teacher and trainer factors (Kangalgil et al., 2006). Attitudes are classified as positive and negative attitudes. Positive attitude is positive approach to events, having a constructive thought, assimilation, love and interest. Negative attitude is to behave negatively towards an object or a way of thinking (Şişko \& Demirhan, 2002).

\section{Method}

\subsection{Research Model}

Relational screening method which is one of the research methods, was used. Questionnaires in the research were applied to the participants by face to face interview method.

\subsection{Data Collection Tools}

The questionnaire form consisting of two parts was used in the research. In the first part of the questionnaire, there were demographic questions consisting of 8 items. In the second part of the questionnaire, "Sport-Oriented Attitude Scale" was used which is composed of 28 items and 3 sub-dimensions and validity and reliability study of the scale was performed by Şentürk (2015).

\subsection{Population and Sample}

The population of the research consists of 382 students studying at the University of Health Sciences Hamidiye Vocational School of Health Care Services. A preliminary study was conducted to determine the number of people to be included in the study, and the comparison that required the most sample size was found to be the comparison between the genders. Calculations were made using the PASS 2008 package program. As a result of the calculations, it was concluded that 180 students, 90 for each gender group, should be included in the sample for power of $0.99(\alpha=0.05 ; \mu 1=2.81 ; \mu 2=3.97 ; \mathrm{S} 1=1.21 ; \mathrm{S} 2=1.37 ; \mathrm{R}=1)$. The research was applied to 407 people in total and 25 forms were not included because they were not suitable for the research. The number of forms included in the study was limited to 382 people.

\subsection{Data Analysis}

The analysis of the data was carried out by using the IBM SPSS 25 package program. Firstly, frequency (n) and percentage (\%) values of the participants' demographic information were presented. In order to examine the differences between the categories of demographic variables in terms of scale scores, independent sample $\mathrm{T}$ test was used to compare variables with scale scores with two categories, and one-way ANOVA methods were used to compare variables with more than two categories with scale scores.

In case the difference is detected as a result of one-way ANOVA analysis; Bonferroni Test, one of the post-hoc methods was used and the category or categories from where the difference originated was determined. In the study, the type I error rate was taken as 0.05 . 
Table 1. Personnel information of participants

\begin{tabular}{lll}
\hline & $\mathrm{f}$ & $\%$ \\
\hline Gender & & \\
\hline Male & 99 & 25.9 \\
\hline Female & 283 & 74.1 \\
\hline Age & & \\
\hline $18-22$ & 334 & 87.4 \\
\hline $23-27$ & 24 & 6.3 \\
\hline 28 and above & 24 & 6.3 \\
\hline Doing sport status & & \\
\hline Regularly & 50 & 13.1 \\
\hline Occasionally & 129 & 33.8 \\
\hline Rarely & 137 & 35.9 \\
\hline Never & 66 & 17.3 \\
\hline Monthly family income & & \\
\hline Minimum wage & 108 & 28.3 \\
\hline 2101-3000 TL & 80 & 20.9 \\
\hline 3001-4000 TL & 80 & 20.9 \\
\hline 4001-5000 TL & 66 & 17.3 \\
\hline 5001 TL and above & 48 & 12.6 \\
\hline Health Status & & \\
\hline I am healthy & 274 & 71.7 \\
\hline I get sick very often & 22 & 5.8 \\
\hline I have minor complaints & 68 & 17.8 \\
\hline I have a chronic disease & 18 & 4.7 \\
\hline Place of residence & & \\
\hline Subprovince & 48 & 12.6 \\
\hline Province & 24 & 6.3 \\
\hline Metropolis & 310 & 81.2 \\
\hline & & \\
\hline
\end{tabular}

\section{Results}

Table 2. Comparison of scale scores of the participants in terms of gender

\begin{tabular}{ccccccc}
\hline & Gender & Mean & Sd. & T & $\mathrm{p}$ \\
\hline \multirow{2}{*}{ Being interested in sport } & Male & 3.57 & 0.75 & & \multirow{2}{*}{4.865} & $<0.001^{*}$ \\
\cline { 2 - 5 } & Female & 3.11 & 0.82 & & \\
\hline \multirow{2}{*}{ Giving importance to sport } & Male & 3.35 & 0.76 & \multirow{2}{*}{3.811} & $<0.001^{*}$ \\
\cline { 2 - 5 } & Female & 3.00 & 0.78 & & \\
\hline \multirow{2}{*}{ Doing sport actively } & Male & 3.33 & 0.83 & \multirow{2}{*}{4.671} & $<0.001^{*}$ \\
\cline { 2 - 5 } & Female & 2.89 & 0.80 & & \\
\hline
\end{tabular}

$* \mathrm{p}<0.05$.

As a result of comparing the scale scores of the participants in terms of their gender; It was found that males had higher scores in terms of being interested in sport $(p<0.001)$, giving importance to sport $(p<0.001)$ and doing sport actively $(\mathrm{p}<0.001)$ when compared to females (Table 2$)$. 
Table 3. Comparison of scale scores of participants in terms of age groups

\begin{tabular}{ccccccc}
\hline & Age group** & Mean & Sd. & F & p & Difference \\
\hline \multirow{3}{*}{ Being interested in sport } & A & 3.22 & 0.84 & & & \\
& B & 2.95 & 0.66 & 5.259 & $0.006^{*}$ & C $>$ A,B \\
& C & 3.69 & 0.61 & & & \\
\hline \multirow{3}{*}{ Giving importance to sport } & A & 3.08 & 0.80 & & & \\
& B & 2.86 & 0.70 & 3.649 & $0.027^{*}$ & C $>$ A,B \\
& C & 3.46 & 0.69 & & & \\
\hline \multirow{3}{*}{ Doing sport actively } & A & 3.02 & 0.84 & & & \\
& B & 2.61 & 0.76 & 4.107 & $0.017^{*}$ & C $>$ A,B \\
& C & 3.28 & 0.62 & & & \\
\hline
\end{tabular}

${ }^{*} \mathrm{p}<0.05 ; * * \mathrm{~A}: 18-22 ; \mathrm{B}: 23-27 ; \mathrm{C}: 28$ and above.

As a result of comparing the scale scores of the participants in terms of age groups; It was found that students aged 28 and above had higher scores in comparison to other participants in terms of being interested in sport $(\mathrm{p}<0.006)$, giving importance to sport $(\mathrm{p}<0.027)$ and doing sport actively $(\mathrm{p}<0.017)$ (Table 3$)$.

Table 4. Comparison of scale scores of the participants in terms of their sports status

\begin{tabular}{ccccccc}
\hline & Sport** & Mean & Sd. & F & p & Difference \\
\hline & A & 3.82 & 0.80 & & & \\
Being interested in sport & B & 3.48 & 0.69 & 30.450 & $<0.001^{*}$ & A $>$ B $>$ C $>$ D \\
& C & 3.05 & 0.78 & & & \\
& D & 2.68 & 0.72 & & & \\
\hline \multirow{5}{*}{ Giving importance to sport } & A & 3.67 & 0.81 & & & \\
& B & 3.38 & 0.68 & & & \\
& C & 2.90 & 0.67 & 37.373 & $<0.001^{*}$ & A $>$ B $>$ C $>$ D \\
& D & 2.51 & 0.70 & & & \\
\hline \multirow{5}{*}{ Doing sport actively } & A & 3.58 & 0.74 & & & \\
& B & 3.34 & 0.75 & 41.439 & $<0.001 *$ & A $>\mathrm{B}>\mathrm{C}>\mathrm{D}$ \\
& C & 2.80 & 0.71 & & & \\
\hline
\end{tabular}

${ }^{*} \mathrm{p}<0.05 ;{ }^{* * A}$ : Regularly; B: Occasionally; C: Rarely; D: Never.

As a result of comparing the scale scores of the participants in terms of their sports status; there was a significant difference in being interested in sport $(\mathrm{p}<0.001)$, giving importance to sport $(\mathrm{p}<0.001)$ and doing sport actively $(\mathrm{p}<0.001)$ levels. It was observed in all sub-dimensions that the students who do sport regularly have the highest scores and the students who do sports occasionally have higher scores than other students. It was found that students who never do sports have the lowest scores, and students who do sports rarely have higher scores than students who never do sports and have lower scores than other students (Table 4). 
Table 5. Comparison of scale scores of the participants in terms of family monthly income levels

\begin{tabular}{ccccccc}
\hline & Family income ** & Mean & Sd. & F & p & Difference \\
\hline & A & 3.33 & 0.95 & & & \\
Being interested in sport & B & 3.03 & 0.73 & & & \\
& C & 3.17 & 0.73 & 2.151 & 0.074 & - \\
& D & 3.29 & 0.83 & & & \\
& E & 3.38 & 0.79 & & & \\
Giving importance to sport & A & 3.20 & 0.91 & & & \\
& B & 2.83 & 0.74 & & & \\
& C & 3.00 & 0.58 & 3.957 & $0.004^{*}$ & B $<$ A,C,D,E \\
& D & 3.22 & 0.89 & & & \\
\hline \multirow{5}{*}{ Doing sport actively } & E & 3.25 & 0.67 & & & \\
& A & 3.03 & 0.78 & & & \\
& B & 2.73 & 0.87 & & & \\
& C & 3.08 & 0.72 & 3.573 & $0.007 *$ & B $<A, C, D, E$ \\
& D & 3.06 & 0.89 & & & \\
\hline & E & 3.23 & 0.84 & & & \\
\hline
\end{tabular}

${ }^{*} \mathrm{p}<0.05 ;{ }^{* *} \mathrm{~A}:$ Minimum wage; B: 2101-3000 TL;C: 3001-4000 TL;D: 4001-5000 TL; E: 5001 TL and above.

As a result of comparing the scale scores of the participants in terms of family monthly income levels; It was found that there was no significant difference in terms of being interested in sport $(p<0.074)$, there was a significant difference in terms of giving importance to sport $(p<0.004)$ and doing sport actively $(p<0.007)$. In terms of giving importance to sport and doing sport actively; participants with family monthly income between 2101-3000 TL were found to have the lowest scores (Table 5).

Table 6. Comparison of scale scores in terms of participants' health status

\begin{tabular}{cccccc}
\hline & Health Status** & Mean & Sd. & F & p \\
\hline \multirow{5}{*}{ Being interested in sport } & A & 3.21 & 0.82 & & \\
& B & 3.48 & 0.85 & & \\
& C & 3.27 & 0.89 & 1.019 & 0.384 \\
& D & 3.06 & 0.56 & & \\
\hline \multirow{5}{*}{ Giving importance to sport } & A & 3.10 & 0.78 & & \\
& B & 3.25 & 0.95 & 0.541 & 0.654 \\
& C & 3.05 & 0.84 & & \\
\hline \multirow{5}{*}{ Doing sport actively } & D & 2.95 & 0.52 & & \\
& A & 2.97 & 0.85 & & \\
& B & 3.36 & 1.07 & & \\
& C & 3.05 & 0.72 & 1.690 & 0.169 \\
\hline
\end{tabular}

${ }^{*} \mathrm{p}<0.05 ;{ }^{* *} \mathrm{~A}$ : I am healthy; B: I get sick very often; C: I have minor complaints; D: I have a chronic disease.

As a result of comparing the scale scores of the participants in terms of their health status; there was no significant difference in being interested in sport ( $p>0.384)$, giving importance to sport $(p>0.654)$ and doing sport actively ( $>0.169)$ levels (Table 6). 
Table 7. Comparison of scale scores of the participants in terms of their place of residence

\begin{tabular}{ccccccc}
\hline & Place of residence** & Mean & Sd. & F & P & Difference \\
\hline \multirow{3}{*}{ Being interested in sport } & A & 3.17 & 0.89 & & & \\
& B & 3.64 & 0.79 & 3.211 & $0.041^{*}$ & B $>$ A,C \\
& C & 3.21 & 0.81 & & & \\
\hline \multirow{3}{*}{ Giving importance to sport } & A & 2.87 & 0.96 & & & \\
& B & 3.42 & 0.81 & 4.110 & $0.017^{*}$ & B $>$ A,C \\
& C & 3.10 & 0.75 & & & \\
\hline \multirow{3}{*}{ Doing sport actively } & A & 2.85 & 0.81 & & & \\
& B & 3.26 & 0.74 & 2.021 & 0.134 & - \\
\hline
\end{tabular}

${ }^{*} \mathrm{p}<0.05 ; * * \mathrm{~A}$ : Subprovince; B: Province; C: Metropolis.

As a result of comparing the scale scores of the participants in terms of their place of residence; it was found that there was a difference in terms of being interested in sport $(p<0.041)$ and giving importance to sport $(p<0.017)$, and there was no significant difference in terms of doing sport actively $(p<0.134)$ levels. It was observed that students living in the province had higher scores than other students in terms of being interested in sport and giving importance to sport (Table 7).

\section{Discussion}

In the study of Yildiz et al. (2017) on the attitudes of university students towards sports, the results about gender variables showed that there was a statistically significant difference in terms of sports attitude total score according to Psychosocial Development subdimension and Physical Development subdimensions. In addition, a statistically significant difference was found in sports participation scores. In the study of Turkmen et al. (2016), a statistically significant difference was found in male and female students' attitudes towards sports. In the study of secondary school students 'attitudes towards physical education lesson sought by Güllü (2007), it was found that male students 'attitude scores towards physical education and sports lessons were higher than female students' attitude scores and a significant difference was found according to gender. In the study conducted by Alemdağ et al. (2014) on form teacher candidates, a statistically significant difference was obtained in the results regarding gender variables. Şişko and Demirhan (2002) found a significant difference in terms of gender in their study of primary and high school students' sports attitudes. In the study conducted by Varol et al. (2017) on university students, a significant difference was found between male and female students in the gender variable. In the study conducted by Taşkın and Tekin (2009) on secondary school students, it was found that male students have higher sports attitude scores than female students. In the study conducted by Kangalgil et al. (2006), the difference that emerged according to gender supported the results of other studies. Consequently, it was concluded that male students had higher attitude scores.

In the study of Yanık and Çamlıyer (2015), who reported opposite results of the results of this study and other studies, there was no significant difference in attitudes of participants towards physical education lesson and sports according to gender. In the study of Göksel and Caz (2016), no statistically significant difference was found between male and female students. Another researcher, Göksel et al. (2017) did not find a significant difference between male and female students in their sports attitudes. The conclusion of these results contradicts the results of our study. This contradiction may have resulted from different reasons such as the difference in the sample group of the researches, application differences, researchers and the environment.

Another study that varies in gender was carried out by Gökdağ (2018) on school administrators; it was found that female managers' attitude scores were higher than the male managers' attitude scores in the subdimension of "Being Interested in Sports". Caz et al. (2019) found a statistically significant difference in students' attitudes towards sports by gender variable and reached similar results. The average scores of female students were higher than the average scores of male students. In contrast to the results of other studies, a significant difference was found in favor of females. The results obtained by the researchers showed a similarity on the differences in the gender variable of our study. However, the difference in the outcome from our study is that the part that is favored is opposite of males. In this sense, it does not resemble our study. It can be said that this situation is due to the difference in the sample group.

In the study conducted by Smoll and Shutz (1980) on sportive attitudes of the people who participated in physical activities, it was found that men had higher sportive attitude scores than women and there was a statistically 
significant difference in favor of males. From the results that support the results of this study, Tükel (2018) obtained results that males have higher scores when compared to females in sporting attitudes in general. In the study conducted by Ünal et al. (2001), it was concluded that there were significant relationships in the attitude which points towards sports in the evaluation of gender variables. In the study conducted by Singh and Devi (2013) on university students in India, it was found that male students showed a more positive attitude towards games and sports than female students.

In our study, it was concluded that males' attitudes towards sports are more intense when compared to females, and as their sport involvement increases, their attitudes towards sports increases as well. These results are similar to the results of the studies of the researchers in the literature. In the study conducted by Kjønniksen et al. (2009), on the adolescent students' attitudes towards physical education lesson, it was found that 13-16 year old students' sports attitudes had higher scores. This is similar to the results of our study. The attitude points of the individuals who do sports are also obtained in parallel with this.

Therefore, it is obvious that the results of the researchers above support our own study. In the findings of our study, it was observed that the main factors determining sport attitude are variables such as place of residence, income level, age and gender, and there were statistically significant differences between these variables.

\section{Suggestions}

It was concluded that the levels of being interested in sport $(p<0.001)$, giving importance to sport $(p<0,001)$ and doing sport actively $(\mathrm{p}<0.001)$ scores were higher in males than in females, and so the statistical difference that was found between them was in favor of the males.

It was found that participants who were 28 years old and above had higher scores than others in terms of being interested in sport $(\mathrm{p}<0.006)$, giving importance to sport $(\mathrm{p}<0.027)$ and doing sport actively $(\mathrm{p}<0.017)$ and there was a statistically significant difference between them.

It was observed that the participants' sports status created significant differences in terms of being interested in sport $(\mathrm{p}<0.001)$, giving importance to sport $(\mathrm{p}<0.001)$ and doing sport actively $(\mathrm{p}<0.001)$. When the order of scoring was ranked from the highest to the lowest, the order was: students do sports regularly, students do sports occasionally, students do sports rarely and students never do sports. Therefore, it was concluded that the students who never do sports have the lowest scores (Doing sport regularly $>$ Doing sport occasionally $>$ Doing sport rarely $>$ Never do sports $),(p<0.05)$. When the family monthly income levels of the participants were examined, it was observed that the participants who had income level between 2101-3000 TL, had the lowest scores in terms of being interested in sport $(p<0.004)$ and doing sport actively $(p<0.007)$, and there was a statistically significant difference between them and the other participants.

According to place of residence of the participants, it was found that there was a significant difference in terms of being interested in sport $(\mathrm{p}<0.041)$ and giving importance to sport $(\mathrm{p}<0.017)$. It was found that students living in the province had higher scores than other students. Sports fields should be created in places where individuals live in order to develop their behavior towards sports. Time should be created for individuals to do sports and have fun. At the same time, their economic well-being should be pursued, and an enabling environment should be created where they can do sports activities.

\section{References}

Alemdağ, S., Öncü, E., \& Sakallığlu, F. (2014). Sınıf Öğretmeni Adaylarının Beden Eğitimi Dersine Yönelik Tutum Ve Öz Yeterlikleri. Abant İzzet Baysal Üniversitesi Eğitim Fakültesi Dergisi, 14(2), 45-60. https://doi.org/10.17240/aibuefd.2014.14.2-5000091527

Aydoğan, Y., Özyürek, A., \& Akduman, G. G. (2015). Okul Öncesi Dönem Çocuklarının Spora İlişkin Görüşlerinin İncelenmesi. International Journal of Science Culture and Sport, 4(Special Issue 1), 103-115. https://doi.org/10.14486/IJSCS265

Caz, Ç., Bıçakçı, Y. S., \& Nakipoğlu, F. F. (2019). Spora Yönelik Tutum İle Yaşam Doyumu Arasındaki İlişki: Marmara Üniversitesi Sosyal Bilimler Meslek Yüksekokulu Öğrencileri Örneği. Gümüşhane Üniversitesi Sosyal Bilimler Enstitüsü Elektronik Dergisi, 10(3).

Çelik, Z., \& Pulur, A. (2011). Ortaöğretim Öğrencilerinin Beden Eğitimi ve Spora İlişkin Tutumları. VAN/YYÜ Eğitim Fakültesi Dergisi Özel Saylsı, 115-121.

Demirhan, G., \& Altay, F. (2001). Lise Birinci Sınıf Öğrencilerinin Beden Eğitimi ve Spora İlişkin Tutum Ölçeği 2. Hacettepe Spor Bilimleri Dergisi, 12(2), 9-20.

Doydu, İ., Çelen, A., \& Çoknaz, H. (2013). Spor Eğitim Modelinin Öğrencilerin Beden Eğitimi ve Spora Karşı 
Tutumuna Etkisi. E-International Journal of Educational Research, 4(2), 99-110.

Erkan, E. (1992). Toplum Sağlığı Açısından Spor. In E. Ergen (Ed.), Spor Hekimliği. Ankara: Maya Matbaacılık Yayıncılık Ltd. Şti.

Filiz, K. (2002). Sporun Tanımlanması Ve Kapsamının Belirlenmesi Üzerine Bir Çalışma. G. ̈̈. Gazi Ĕgitim Fakültesi Dergisi, 22(2), 203-211.

Gökdağ, M. (2018). Okul Yöneticilerinin Spora Yönelik Tutumları ve Kadınların Spor Etkinliklerine Katılımlarına Dair Görüşlerinin Araştırılması (Bartın Örneği). Yayımlanmamış Yüksek Lisans Tezi, Bartın: Bartın Üniversitesi, Eğitim Bilimleri Enstitüsü, Beden Eğitimi ve Spor Öğretmenliği Ana Bilim Dalı.

Göksel, A. G., \& Caz, Ç. (2016). Anadolu Lisesi Öğrencilerinin Beden Eğitimi Dersine Yönelik Tutumlarının İncelenmesi. Marmara Üniversitesi Spor Bilimleri Dergisi, 1(1), 1-9. https://doi.org/10.22396/sbd.2016.0

Göksel, A. G., Caz, Ç., Yazıcı, Ö. F., \& İkizler, H. C. (2017). Farklı Bölümlerdeki Öğrencilerin Spora Yönelik Tutumlarının Karşılaştırılması: Marmara Üniversitesi Örneği. Spor ve Performans Araştırmaları Dergisi, 8(2), 123-134. https://doi.org/10.17155/omuspd.322783

Güllü, S., \& Çiftçi, E. G. (2016). Spor Merkezlerine Üye Olan Bireylerin Yaşam Kalitesinin İncelenmesi. International Journal of Social Sciences and Education Research, 2(3), 1251-1265.

Hünük, İ. (2006). Ankara İli Merkez İçelerindeki İlköğretim İkinci Kademe Öğrencilerinin Beden Eğitimi Dersine İlişkin Tutumlarının Sınıf Düzeyi, Öğrenci Cinsiyeti, Öğretmen Cinsiyeti ve Spora Aktif Katılımları Açısından Karşılaştırılması. Yayınlanmamış Yüksek Lisans Tezi, Hacettepe Üniversitesi Sağlık Bilimleri Enstitüsü Spor Bilimleri ve Teknolojisi Programı, Ankara: Türkiye.

İlhan, L. (2008). Eğitilebilir Zihinsel Engelli Çocuklarda Beden Eğitimi Ve Sporun Sosyalleşme Düzeylerine Etkisi. Kastamonu Ë̆itim Dergisi, 16(1), 315-324.

Kağıtçıbaşı, Ç. (1999). Insan ve İnsanlar. İstanbul: Evrim Yayınları.

Kangalgil, M., Hünük, D., \& Demirhan, G. (2006). İlköğretim, Lise ve Üniversite Öğrencilerinin Beden Eğitimi ve Spora İlişkin Tutumlarının Karşılaştırılması. Hacettepe Spor Bilimleri Dergisi, 17(2), 48-57.

Kat, H. (2009). Bireysel Sporcularla Takım Sporcularının Stres Düzeyleri Ve Problem Çözme Becerilerinin Karşılaştırılması. Yüksek Lisans Tezi, Erciyes Üniversitesi, Kayseri.

Kjønniksen, L., Fjørtoft, I., \& Wold, B. (2009). Attitude to Physical Education And Participation İn Organized Youth Sports During Adolescence Related To Physical Activity in Young Adulthood: A 10-Year Longitudinal Study. European Physical Education Review, 15(2), 139-154. https://doi.org/10.1177/1356336X09345231

Şentürk, H. E. (2015). Sportif Tutum Ölçeği: Geliştirilmesi, Geçerliliği ve Güvenirliği. Celal Bayar Üniversitesi Beden Eğitimi ve Spor Bilimleri Dergisi, 7(2), 8-18.

Singh, R. K. C., \& Devi, K. S. (2013). Attitude of Higher Secondary Level Student Towards Games and Sports. International Journal of Physical Education, Fitness And Sports, 2(4), 80-85. https://doi.org/10.26524/13421

Şişko, M., \& Demirhan, G. (2002). İlköğretim Okulları ve Liselerde Öğrenim Gören Kız ve Erkek Öğrencilerin Beden Eğitimi Spor Dersine İlişkin Tutumları. Hacettepe Üniversitesi Eğitim Fakültesi Dergisi, 23, 205-210.

Smoll, F. L., \& Schutz, R. V. (1980). Children's Attitudes Towards Physical Activity: A Longitudial Analysis. Journal of Sport Psychology, 2, 137-147. https://doi.org/10.1123/jsp.2.2.137

Solmaz, B., \& Aydın, B. O. (2012). Popüler Kültür ve Spor Merkezlerine Yönelik Bir Araştırma. Gümüşhane Üniversitesi Iletişim Fakültesi Elektonik Dergisi, 1(4), 67-82.

Strong, W. B., Malina, R. M., Blimkie, C. J., Daniels, S. R., Dishman, R. K., Gutin, B., \& Rowland, T. (2005). Evidence based physical activity for school-age youth. The Journal of pediatrics, 146(6), 732-737. https://doi.org/10.1016/j.jpeds.2005.01.055

Taşkın, Ö., \& Tekin, M. (2009). Çeşitli Değişkenlere Göre İlköğretim ve Orta Öğretim Kurumlarında Öğrenim Gören Öğrencilerin Beden Eğitimi ve Spor Dersine İlişkin Tutum ve Görüşleri. Kastamonu Eğitim Dergisi, $17(2), 457-466$.

Tükel, Y. (2018). Rekreatif Amaçlı Spor Yapanların Spora Yönelik Tutumlarının Cinsiyete ve Medeni Duruma Göre Değerlendirilmesi. Sportive Spor, Ĕ̈itim ve Rekreasyon Dergisi, 1(1), 12-18. 
Turğut, M., \& Yaşar, O. M. (2019). Psikolojik Yardım Alma Tutumu ve Spor. Iğdır Üniversitesi Spor Bilimleri Dergisi, 2(1), 1-15.

Türkmen, M., Abdurahimoğlu, Y., Varol, S., \& Gökdağ, M. (2016). İslami İlimler Fakültesi Öğrencilerinin Spora Yönelik Tutumlarının İncelenmesi (Bartın Üniversitesi Örneği). International Journal of Contemporary Educational Studies, 2(1), 48-59.

Ünal, S., Karlıdağ, R., \& Yoloğlu, S. (2001). Hekimlerde Tükenmişlik ve İş Doyumu Düzeylerinin Yaşam Doyumu Düzeyleri İle İlişkisi. Klinik Psikiyatri, 4, 113-118.

Varol, R., Varol, S., \& Türkmen, M. (2017). Bartın Üniversitesinde Öğrenim Gören Öğrencilerin Spora Yönelik Tutumlarının Belirlenmesi. International Journal of Cultural and Social Studies, 3(2), 316-329.

Yanık, M., \& Çamlıyer, H. (2015). Ortaöğretim 9. Sınıf Öğrencilerinin Beden Eğitimi Ve Spora İlişkin Tutumları İle Okula Yabancılaşma Düzeyleri Arasındaki İlişkinin Belirlenmesi. Uluslararası Spor, Egzersiz ve Antrenman Bilimi Dergisi, 1(1), 9-19. https://doi.org/10.18826/ijsets.95709

Yaşar, O. M. (2020). Spor Sektöründe İş Fırsatları. Spor Yayınevi ve Kitapevi.

Yetim, A. (2000). Sosyoloji ve Spor. Topkar Matbaacilık, Ankara.

Yetim, A. (2011). Sosyoloji ve Spor. Ankara: Berikan Yayınevi.

Yıldırım D. A., Yıldırım E., Ramazanoğlu F., Uçar Ü., Tuzcuoğulları Ö. T., \& Demirel E. T. (2006). Üniversite öğrencilerinin spora bakış açıları ve spor yapma durumu. Doğu Anadolu Araştırmaları, 4(3), 49-53.

Yıldız, A. B., Arı, Ç., \& Yılmaz, B. (2017). Üniversite Öğrencilerinin Spora Yönelik Tutumlarının İncelenmesi (Ankara Yıldırım Beyazıt Üniversitesi Örneği). Muş Alpaslan Üniversitesi Uluslararası Spor Bilimler Dergisi, 1(1), 35-45.

\section{Copyrights}

Copyright for this article is retained by the author(s), with first publication rights granted to the journal.

This is an open-access article distributed under the terms and conditions of the Creative Commons Attribution license (http://creativecommons.org/licenses/by/4.0/). 